\title{
Deep Brain Stimulation for Parkinson's Disease; Challenges, Raising Hopes and Concerns
}

\author{
Mohammad Sharif Sharifi*, Renata Andrzejewska and Neda Blackwood \\ Australian Food and Pharmaceutical Industries, Australia
}

Submission: June 15,2018; Published: August 24, 2018

*Corresponding author: Mohammad Sharif Sharifi, Australian Food and Pharmaceutical Industries (AFPI), 5 McIntyre Way Bomaderry, NSW, Australia; Tell: +61 421287461; Email:m.sharifi@foodpharmaindu.com

\begin{abstract}
The technology of Neural Stimulation became the focus of research and treatment during 2010-2013, though it has been around for many years. However, it has slowed down dramatically since 2013 for many reasons, in particular, gene therapy. The potential uses of stimulating the brain and nerves ranges from spinal cord stimulation to the implantations of cochlear and bionic eyes. We will focus on Parkinson's disease in this paper as it produces effective results and is popular with many patients. Electrical high-frequency Deep Brain Stimulation (DBS) was developed as an alternative option to treat several neurological disorders. The applications of DBS are expanding not only for therapeutic purposes, but also for research. Although the exact mechanisms of action/s are not fully understood, the outcome of the ongoing research and clinical trials are promising, in particular with Parkinson's disease. DBS has been used to treat the essential tremor since 1997, Parkinson's disease (PD) since 2002, and dystonia since 2003. It has also been used to treat various disorders, including major depression and Obsessive-Compulsive Disorder.

Keywords: Deep Brain Stimulation; Parkinson's Disease; Neural stimulation; Treatment; Brain; Disorders; Chronic progressive; Population; Hippocampus; Alzheimer's disease; Locus coeruleus; Nigra; Symptoms; Efficiency; Tremors; Mental problems; Dysphagia; Depression; Stimulation; Quality of life; Frequency
\end{abstract}

Abbreviations: DBS: Deep Brain Stimulation; PD: Parkinson's Disease

\section{Introduction}

Parkinson's Disease (PD) is a chronic progressive disorder of the central nervous system, gradually impairing the functioning of those affected [1]. The prevalence of PD in the general population is about $0.15 \%$ and increases with age; $1.8 \%$ above 65 years of age and $2.6 \%$ above 85 years of age [2]. The essence of the pathological process underlying PD is degeneration and the disappearance of dopaminergic neurons in the substantia nigra of the midbrain. The development of the pathological process in PD lasts for many years and was divided by Braak into six stages. Characteristic inclusion bodies are present in all stages; Lewy neurites within the cellular spines and the round Lewy bodies within the nerve cells. However, Lewy neurites are not pathognomonic of $\mathrm{PD}$, they were also found in the CA2-3 region of hippocampus in Alzheimer's disease [3,4].

Lewy neurites and bodies occur in the central and peripheral nervous system and contain mainly neurofilament proteins: alpha-synuclein and ubiquitin. The neurodegenerative process in PD proceeds in a sequential manner starting from predisposed places in the spinal cord and the medulla oblongata, eventually taking up other susceptible regions of grey matter. Stage 1 involves degeneration of the dorsal motor nucleus of the vagal nerve, the adjoining reticular zone and the olfactory bulb. Similar pathological changes also appear in some neurons of the autonomic system, for example in the neurons of the Auerbach plexus. In the next pre-symptomatic stage, degenerative changes intensify and include the raphe nuclei, nucleus reticularis parvocellular and the locus coeruleus (stage 2). The substantia nigra becomes affected in stage 3 , along with other basal portions of the midbrain and forebrain; Lewy neurites appear for the first time in the amygdala and in the nucleus basalis of Meynert. At this stage, after crossing the individual neuropathological threshold, symptoms of the disease appear [3,4]. In the next stage, the pathological process begins to involve the temporal mesocortex (stage 4), and in the final stages (stage 5 and 6) the entire neocortex is affected [4].

Symptoms of PD are often nonspecific, they are also associated with many other diseases and initially discreet. They can be preceded by pain diagnosed as sciatica, brachialis tendonitis and sometimes also olfactory disorders. Symptoms can include: reduced efficiency, general slowing down and impoverishment of movements, tremors, increased muscle tone, indistinct speech, balance disorders, sudden blockage 


\section{Open Access Journal of Neurology \& Neurosurgery}

of movement while walking, mental problems, dysphagia, depression and vegetative disorders. Parkinson's disease cannot be cured, but existing therapies can help control the symptoms. This could be achieved either by administration of medicines or surgical procedures [5].

\section{Discussion}

One of the first attempts to treat PD was supplementing the deficiency of dopamine. But since dopamine itself does not pass the blood-brain barrier, the administration of this neurotransmitter to the blood would have no effect. Researchers found that L-DOPA, the precursor from which dopamine is formed does pass through the blood-brain barrier. The introduction of L-DOPA was a breakthrough in the fight against PD. L-DOPA is administered peripherally together with enzyme inhibitors converting L-DOPA into dopamine. These inhibitors do not cross the blood-brain barrier. In the dopaminergic neurons of the brain, L-DOPA is transformed into dopamine. Unfortunately, L-DOPA does not prevent the death of dopamine-producing cells. In most cases, the patient's body responds positively to L-DOPA only for the first few years, and then, when the number of L-DOPA transforming neurons in dopamine decreases, it is necessary to increase the dose of L-DOPA, which leads to many undesirable side effects [6-10]. Another treatment strategy is to inhibit the degradation process of dopamine that has already been released from neurons which can be done by inhibiting the COMT or MAO-B enzymes. The administration of dopamine receptor agonists (substances that mimic the effects of dopamine) is also very common. Their task is to stimulate dopamine receptors in the brain [11-14].

One of the surgical strategies for the treatment of PD is transplantation of cells capable of producing dopamine; these cells can come directly from the patient's body or from human foetuses. The use of cells derived from the patient proved ineffective as these cells are in small quantities and die rapidly after transplantation. In Sweden and The United States, treatments are performed involving the implantation of foetal brain tissue in patients with advanced PD. However, the use of cells originating from human foetuses for therapeutic purposes raises ethical issues [15-17].

The most promising method of treating PD is Deep Brain Stimulation (DBS). During DBS procedures, thin stimulating electrodes are implanted into deeply located parts of the brain [1]. Currently, around 130,000 people live in the world with a brain stimulator. The first DBS treatment in PD was carried out in 1987 in France. Shortly thereafter, it was used in other countries. In 2002, the Food and Drug Administration (FDA) granted approval for treatment of Parkinson's Disease patients with DBS. The implanted electrodes generate electrical impulses that modify the action of the nerve centres responsible for the development of the disease. The pulse generator installed in the patient's body provides a constant source of current. The voltage is very low: 0.1 - $5 \mathrm{~V}$ [1,18-21].
In Parkinson's disease, the electrode is usually implanted in the subthalamic nucleus, less often in the internal globus pallidus or in the lateral nucleus [22]. Interestingly, the cerebral electrode is not implanted in the substantia nigra (the place where dopamine neurons seems to be atrophied in PD) because DBS causes the inhibition of selected nerve structures, not their stimulation. Implantation of an electrode into a substantia nigra would therefore have the opposite effect. Under physiological conditions, dopamine balances other nerve centres and inhibits some of them (in e.STN). In Parkinson's Disease, in the absence of dopamine, there is disinhibition of certain structures, resulting in the appearance of motor symptoms (stiffness, tremors, dyskinesia) [23]. Deep brain stimulation restores balance in the brain centres, relieving the symptoms of PD [1].

The DBS treatment in Parkinson's disease is extremely effective. It allows for significant improvement in movements, reduction of muscle stiffness, hand tremors and reduction of dyskinesia [1]. In the analysis of many studies on DBS in Parkinson's disease, the average improvement in mobility was rated at $52 \%$. This value is averaged based on neurological assessments of patients before and after surgery. The DBS effect assessment is based on the analysis of the quality of life of patients in their daily activities; the DBS effect is usually even greater [24 -26]. In 2013 we published a paper [1] raising hope for DBS in PD treatment. However, we would like to mention some side effects associated with DBS in this review. Having said that, DBS is highly recommended for those severely affected by PD with low quality of life. Any surgery involves risk, particularly when it involves the brain's delicate structures. There is a risk of bleeding or infection after the procedure. Side effects resulting from stimulation include; the possibility of speech deterioration, emotional disorders (depression, hypomania, suicide attempts) and the risk of deterioration of cognitive functions (mainly in terms of executive functions and verbal fluency) $[27,28]$.

In 2017, a team of scientists published a paper titled "Noninvasive deep brain stimulation via temporally interfering electric fields" giving a new hope to PD patients. Grossman et al. conducted experiments proving that DBS is possible without invasive surgery. Basically, the stainless-steel plate was affixed to the skull of mice and electrodes were connected to the plate. Then a low to high frequency $(10 \mathrm{~Hz}-2 \mathrm{kHz})$ electric current was applied and the demodulating of neurons was observed. These experiments are very promising, however, extensive studies in this direction is needed $[29,30]$.

\section{References}

1. Sharifi MS (2013) Treatment of neurological and psychiatric disorders with deep brain stimulation; raising hopes and future challenges. Basic Clin Neurosci 4(3): 266 - 270.

2. De Lau LM, Breteler MM (2006) Epidemiology of Parkinson's disease. Lancet Neurol 5(6): 525 - 535.

3. Braak H, Ghebremedhin E, Rüb U, Bratzke H, Del Tredici K (2004) Stages in the development of Parkinson's disease-related pathology. Cell Tissue Res 318(1): 121-134 


\section{Open Access Journal of Neurology \& Neurosurgery}

4. Braak H, Del Tredici K, Rüb U, de Vos RA, Jansen -Steur EN, et al (2003) Staging of brain pathology related to sporadic Parkinson's disease. Neurobiol Ageing 24(2): 197-211.

5. Twelves D, Perkins KS, Counsell C (2003) Systematic review of incidence studies of Parkinson's disease. Mov Disord 18(1): 19-31.

6. Rinne UK, Sonninen V, Siirtola T L-Dopa (1970) Treatment in Parkinson's Disease. Eur Neurol 4: 348-369.

7. Lees AJ L-Dopa (1986) Treatment and Parkinson's Disease. An International Journal of Medicine 59 (3): 535-547.

8. Bauer RB, Stevens C, Reveno WS, Rosenbaum H (1982) L-Dopa Treatment of Parkinson's Disease. Journal of the American Geriatrics Society30 (5): 322-325.

9. Chiu WH, Depboylu C, Hermanns G, Maurer L, Windolph A, et al. (2015) Long-term treatment with l-DOPA or pramipexole affects adult neurogenesis and corresponding non-motor behavior in a mouse model of Parkinson's disease. Neuropharmacology 95: 367-376.

10. Cools R (2006) Dopaminergic modulation of cognitive functionimplications for l-DOPA treatment in Parkinson's disease. Neurosci Biobehav Rev 30 (1): 1-23.

11. Knoll J, Magyar K (1972) Some puzzling pharmacological effects of monoamine oxidase inhibitors. Adv. Biochem Psychopharmacol 5: 393-408.

12. Collins GGS, Sandler M, Williams ED, Youdim MB (1970) Multiple forms of human brain monoamine oxidase. Nature 225: 817-82.

13. Youdim MBH, Collins GGS, Sandler M, Bevan-Jones AB, Pare CM, et al. (1972) Human brain monoamine oxidase, multiple forms and selective inhibitors. Nature 236(5344): 225-228.

14. Youdim MB, Bakhle YS (2006) Monoamine oxidase: isoforms and inhibitors in Parkinson's disease and depressive illness. Br J Pharmacol 147: S287-96.

15. Olanow CW, Goetz CG, Kordower JH, Stoessl AJ, Sossi V, et al. (2003) A double-blind controlled trial of bilateral fetal nigral transplantation in Parkinson's disease. Ann Neurol 54 (3): 403-414.

16. Weiss ML, Medicetty S, Bledsoe R, Shekar Rachakatla R, Choi M, et al. (2006) Human Umbilical Cord Matrix Stem Cells: Preliminary Characterization and Effect of Transplantation in a Rodent Model of Parkinson's Disease. Stem Cells 24(3): 781-792.

17. Wernig M, Pruszak J, Hedlund E, Soldner F, Broccoli V, et al. (2008) Neurons derived from reprogrammed fibroblasts functionally integrate into the fetal brain and improve symptoms of rats with Parkinson's disease. Proc Natl Acad Sci U S A 105 (15): 5856-5861.
18. Pollak P, Benabid AL, Gross C, Gao DM, Laurent A, et al. (1993) Effects of the stimulation of the subthalamic nucleus in Parkinson disease. Rev Neurol (Paris)149(3): 175-176.

19. Gardner J (2013) A history of deep brain stimulation: Technological innovation and the role of clinical assessment tools. Soc Stud Sci 43(5): 707-728.

20. Limousin P, Krack P, Pollak P, Benazzouz A, Ardouin C, et al. (1998) Electrical stimulation of the subthalamic nucleus in advanced Parkinson's disease. N Engl J Med 339(16): 1105-1111.

21. Baizabal-CarvalloJF, Jankovic J (2016) Movement disorders induced by deep brain stimulation. Parkinsonism Relat Disord 25: 1-9.

22. Krause M, Fogel W, Heck A, Hacke W, Bonsanto M, et al. (2001) Deep brain stimulation for the treatment of Parkinson's disease: subthalamic nucleus versus globus pallidus internus. J Neurol Neurosurg Psychiatry 70(4): 464-470

23. Fearnley JM, Lees AJ (1991) Ageing and Parkinson's disease: substantia nigra regional selectivity. Brain 114(pt5): 2283-301.

24. Lozano AM, Dostrovsky J, Chen R, Ashby P (2002) Deep brain stimulation for Parkinson's disease: disrupting the disruption. Lancet neurol 1(4): 225-231.

25. Spottke EA, Volkmann J, Lorenz D, Krack P, Smala AM, et al. (2002) Evaluation of healthcare utilization and health status of patients with Parkinson's disease treated with deep brain stimulation of the subthalamic nucleus. J Neurol 249 (6): 759-766.

26. Moro E, Lozano AM, Pollak P, AgidY, Rehncrona S, et al. (2010) Longterm results of a multicenter study on subthalamic and pallidal stimulation in Parkinson's disease. Mov Disord 25 (5): 578-586.

27. Beric A, Kelly PJ, Rezai A, Sterio D, Mogilner A, et al. (2001) Complications of deep brain stimulation surgery. Stereotact Funct Neurosurg 77(1-4):73-78.

28. ShapiraNA, Okun MS, Wint D, Foote KD, Byars JA, et al. (2006) Panic and fear induced by deep brain stimulation. J Neurol Neurosurg Psychiatry 77(3): 410-412.

29. Grossman N, Bono D, Dedic N, Kodandaramaiah SB, Rudenko A et al. (2017) Noninvasive Deep Brain Stimulation via Temporally Interfering Electric Fields. Cell 169(6): 1029-1041.

30. Marui W, Iskei E, Kato M, AkatsuHN, Kosaka K (2004) Pathological entity of dementia with Lewy bodies and its differentiation from Alzheimer's disease. Acta Neuropathol 108(2): 121-128.

Your next submission with Juniper Publishers
will reach you the below assets
- Quality Editorial service
- Swift Peer Review
- Reprints availability
- E-prints Service
- Manuscript Podcast for convenient understanding
- Global attainment for your research
- Manuscript accessibility in different formats
( Pdf, E-pub, Full Text, Audio)
- Unceasing customer service
Track the below URL for one-step submission
https://juniperpublishers.com/online-submission.php

